\title{
Place of Pheromone in Rape
}

\author{
Kalanghot Padmanabhan Skandhan ${ }^{1 *}$, Osanai Kaoru², Buddhiwanthanally Manohar Mukund ${ }^{3}$, \\ Balakrishnan Sumangala ${ }^{4}$ \\ ${ }^{1}$ Department of Physiology, Sree Narayana Institute of Medical Sciences, Ernakulam, India \\ ${ }^{2}$ Gujarat Ayurveda University, Jamnagar, India \\ ${ }^{3}$ Sree Devaraj Urs Medical College, Kolar, India \\ ${ }^{4}$ Department of Pathology, Sree Narayana Institute of Medical Sciences, Ernakulam, India \\ Email: "kpskandhan@gmail.com
}

Received September 29, 2012; revised October 31, 2012; accepted November 10, 2012

\begin{abstract}
The aim of the study was to find out if pheromone was one of the responsible factors leading to rape. Search in literature revealed many interesting facts. Majority of rape took place on the day or nearer to ovulation. Many rape victims became pregnant. In normal life, among couples most of the sexual intercourse happened on this day, more than on other days. Smell of the women on this day was different and was more attractive to men. Vaginal smell also differed on this day. One study showed many men were able to recognize a woman's urine of ovulation day by its smell. It was not similar on other days. All above lead us to conclude that women exuded a sex attractant or pheromone on the day of ovulation which attracted men. Probably this is the hidden biological cause ending in rape.
\end{abstract}

Keywords: Human Pheromone; Rape; Olfaction; Ovulation; Sexual Attraction

\section{Introduction}

Rape is defined as sexual intercourse by force, duress, intimation or without legal consent [1] or the crime committed by a man of forcing another person to have sexual intercourse with him, without their consent and against their will, especially by the threat or use of violence against them [2]. Law on rape differs in different countries [3-5].

Several aspects of rape are being studied. The rate of rape is increasing world over. The incidence in the USA as reported by Sadock and Sadock [5] was 258,014 in one-year period ending by September 1996. The rate was high between 0.68 and 1.5 million in 2008 [6]. In India a total number of 164,765 cases of crime against women were reported in 2006 which was more than the previous year [7]. Graft and Graft [8] reported a steady increase in the rate of rape from 1951 to 1980 . The age of rape victims varied from 15 months to 82 years [4]. Majority (61\%) of victims were below 18 years of age. Almost $20 \%$ of total victims were below 11 years [5]. Seventy percentage of victims were unmarried [4]. Many times, criminals were known to victims. Most times rapist belonged to same race of victims [9]. This figure was reported from $30 \%$ [4] to 57\% [5]. Half of rape victims were threatened before crime either verbally or with weapons [10]. Lewis et al. [11] reported most common place

\footnotetext{
${ }^{*}$ Corresponding author.
}

for a rape to occur was victim's own house. This was reported as $29 \%$ of total case [5]. Amir [10] reported that $25 \%$ of all rapes were done in group. Rape is not uncommon in prison and jail [12]. The aftermath of rape is a serious matter. Interestingly, only $30 \%$ of the rape was reported. Cause for rape need not be for lust or to revenge. Biologists suspect a hidden cause responsible for rape.

\section{Hypothesis}

The present hypothesis states, " $\mathrm{A}$ human pheromone is likely the hidden biological cause for rape in many cases".

\section{Evidences}

Pheromone is a general term for a chemical synthesized and the smell emitted by an animal initiating a biological action in other animals of the same species. Popularly known sex attractant is a pheromone. Its presence in mammals is well documented [13-20]. Attraction of a bull to a cow in estrous stage is the best example. A similar estrous stage in a woman is not unlikely [21]. Grammer et al. in their review article discussed functioning olfactory communication, role of certain pheromones and beheavioral changes in reproduction [22] though evidences for human pheromone are scanty. The existence of pheromone is not experienced. The probable reasons 
are, during the process of evolution, the requirement of olfaction for searching food or for protection from enemies was slowly excluded, permitting olfactory function into a very negligible state. It was considered as rudimentary [23] or non functional [24]. In case of human, social structure is entirely different from animals; where sex attractant is non essential. This is the main reason for non recognition of pheromones. However, Burton [25] reported that just eight molecules of volatile substances were enough to cause an olfactory sense. A pheromone substance may cause stimulus followed by response.

The following studies indicated the presence of human pheromone in sexual activities. A decreased olfactory acuity was responsible for hypogonadism [26,27] demonstrating olfaction as an important requirement for sexual growth. Synchronization of menstrual cycle [28,29], regular normal menstrual cycle [30-32] as well as ovulation [30] was reported as good examples for pheromonal action. A study conducted by Varendi et al. [33] had shown that a newborn baby was attracted to mother's nipple by smell. In animals this was present and attributed to pheromones.

The possibilities of a male pheromone initiating menarch [34] regulating the normal length of menstrual cycle [32] or desynchronizing menstruation among female students staying at home were reported [29]. The presence of pheromone in secretion of human vagina and sweat glands was shown as important for regularity in sexual activities [35-38]. The vaginal secretions contained volatile fatty acids, which were presumed functioning as pheromones. The constituents of the secretion changed daily according to woman's hormonal status. Human vaginal smell changed according to her menstrual status [39]. Trained police dogs recognized this difference [34].

There are evidences to show a woman gets attracted to a man by smell. Vierling and Rock [40] reported that olfactory sensitivity of women was restricted to reproductive age of life. It increased among women in the middle of menstrual cycle to exaltolide (Lactone of 15-hydroxy pentadecanoic acid) [40] and androstenol, (5 $\alpha$-Androst16-en-3 $\alpha$-ol) two putative human pheromones [41]. Vierling and Rock [40] had observed change in thickness of olfactory epithelium according to the menstrual status.

Evidences for the possible attraction of a man to a woman around ovulation time are available. We consider such attraction is due to one or more pheromones, which support the present hypothesis and are enumerated below:

1) Hurwitz [42] recorded the frequency of coitus throughout the menstrual cycle and observed maximum number of couples had intercourse on the day of ovulation.

2) Fessler [43] repeatedly placed the evidence for coitus taking place during ovulation period.
3) During a month long study among couples, they were instructed not to apply any fragrant substances. The purpose was not to mask the natural smell emitted by them. They were also instructed to record the days when coitus took place. The result showed that maximum number of couples had intercourse on the day of ovulation. Authors believed an attraction between them took place on this day and ended in coitus. In conclusion, the study stated that the sexual intercourse was taking place maximally on the day of ovulation. This was due to the attraction man had to the smell emitted by woman on that day. Authors believed it was pheromone, a sex attractant, and which was responsible for coitus [44].

4) Reports showed primary partners of women were more jealous and possessive near ovulation than at any other level of menstrual cycle [45-47].

5) Doty et al. [38] reported the difference in vaginal odour between the ovulation time and other times. They observed the smell emitted at the time of ovulation was more acceptable to men. Attraction to such smell may be responsible for coitus.

6) Pheromone could be a reason for rape being done on known women [4]. Thirty to fifty seven percentage of victims were belonging to this group [4,5]. The attraction to a woman could have been built up by slowly and repeatedly smelling pheromone [4,5].

7) Keith et al. [48] observed a difference in odor of pre and post coital vaginal secretion. They believed pheromone exuded from women on the day of ovulation, attracted men.

8) In an experimental study conducted, more number of male subjects recognized by smell of female urine collected on the day of ovulation [49]. Exuded pheromone or its metabolic products in urine might be responsible for this. In case of some animals pheromone was present in urine.

9) Fessler [43] reported rape took place during ovulation time and majority of victims became pregnant following crime. Among adult women an estimated 32,101 pregnancies resulted from rape each year [5]. The number revealed the seriousness of the situation that the rape took on the day of ovulation. In many cases of rape pregnancy might not have taken place also. Not necessarily all coitus ended in pregnancy.

\section{Conclusion}

In conclusion, evidences are available that man is attracted to a woman by her smell around ovulation day and this could be a responsible factor in many rape cases. The pheromones under discussion may be responsible for rape in several cases. But may not explain all cases of it, like one in nine-month-old girl [50] or in old age women [51]. 


\section{REFERENCES}

[1] M. B. Pugh and B. Werner, "Stedman's Medical Dictionary,” 27th Edition, Lippincott Williams \& Wilkins, Baltimore, 2000.

[2] E. J. Jewell and F. Abate, Ed., "New Oxford American Dictionary,” Oxford University Press, New York, 2001.

[3] M. Gelder, D. Gath, R. Mayou and P. Cowen, "Oxford Textbook of Psychiatry,” 3rd Edition, Oxford University Press, New York, 1996.

[4] H. I. Kaplan and B. J. Sadock, Eds., "Comprehensive Textbook of Psychiatry," Williams \& Wilkins Publications, Baltimore, 1989.

[5] B. J. Sadock and V. A. Sadock, "Comprehensive Textbook of Psychiatry,” Lippincott, Williams \& Wilkins Publications, Philadelphia, 2000.

[6] B. J. Sadock and V. A. Sadock, "Concise Textbook of Clinical Psychiatry,” Lippincott, Williams \& Wilkins, New Delhi, 2008, p. 419.

[7] M. K. Pathak, P. Agrawal and S. K. Tripathi, "Trends of Sex Related Crime in India and Its Quality Management,” Indian Journal of Forensic Medicine \& Toxicology, Vol. 4, No. 2, 2010.

[8] M. Graft and A. Graft, "Mentally Abnormal Offenders," Bailliere Tindall Publications, Eastbourne, 1984.

[9] B. Fadem, "Behavioral Science," 5th Edition, Lippincott, Williams \& Wilkins, 2009, p. 207.

[10] M. Amir, "Patterns in Forcible Rape,” Chicago University Press, Chicago, 1971.

[11] O. Lewis, C. Sullivan and J. Barraclough, Eds., "The Psychoimmunology of Cancer Mind and Body in the Fight for Survival,” Oxford University Press, Oxford, 1994.

[12] A. J. Beck, P. M. Harrison, M. Berzofsky, R. Caspar and C. Krebs, "Sexual Victimization in Prisons and Jails Reported by Inmates, 2008-2009,” US Department of Justice, Bureau of Justice Statistics Clearing House, Bockville, 2010.

[13] I. Bieber, "Olfaction in Sexual Development and Adult Sexual Organization,” American Journal of Psychotherapy, Vol. 13, 1959, pp. 851-859.

[14] S. Bloch, "A Progesterone Dependent Pheromone of the Female Mouse,” Experientia, Vol. 32, No. 7, 1976, pp. 937-938. doi:10.1007/BF02003779

[15] F. H. Bronson and J. A. Maruniak, "Differential Effects of Male Stimuli on FSH, LH and Prolactin Secretion in Prepubertal Female Mice,” Journal of Endocrinology, Vol. 98, No. 5, 1976, pp. 1101-1108. doi:10.1210/endo-98-5-1101

[16] L. Jasel and C. Aron, "The Role of Pheromones in the Regulation of Estrous Cycle Duration in the Guinea Pig," Neuroendocrinology, Vol. 20, No. 2, 1976, pp. 97-109. doi:10.1159/000122474

[17] R. P. Michael and E. B. Keverne, "Primate Sex Pheromones of Vaginal Origin,” Nature, Vol. 225, No. 5227, 1970, pp. 84-85. doi:10.1038/225084a0

[18] A. P. M. Schalken, "Three Types of Pheromones in the
Domestic Rabbit, Oryctologus cuniculus (L)," Chemical Senses and Flavor, Vol. 2, No. 2, 1976, pp. 139-155. doi:10.1093/chemse/2.2.139

[19] W. K. Whitten, "Modification of the Estrous Cycle of the Mouse by External Stimuli Associated with the Male. Changes in the Estrous Cycle Determined by Vaginal Smears," Journal of Endocrinology, Vol. 17, No. 3, 1958, pp. 307-313. doi:10.1677/joe.0.0170307

[20] W. K. Whitten, "Pheromones and Mammalian Reproduction,” In: A. Mclaren, Ed., Advances in Reproductive Physiology, Academic Press, New York, 1966, p. 155.

[21] K. P. Skandhan, A. Rajahariprasad and B. Sumangala, "Support for Human Estrus: Documentation in Ayurveda," The Journal of Sexual Medicine, Vol. 9, No. 1, 2012, pp. 322-325. doi:10.1111/j.1743-6109.2011.02377.x

[22] K. Grammer, B. Fink and N. Neave, "Human Pheromones and Sexual Attraction," European Journal of $\mathrm{Ob}$ stetrics \& Gynecology and Reproductive Biology, Vol. 118, No. 2, 2005, pp. 135-142. doi:10.1016/j.ejogrb.2004.08.010

[23] A. C. Guyton and J. E. Hall, “Textbook of Medical Physiology," 10th Edition, Elsever Publishers, New Delhi, 2006.

[24] R. H. S. Carpenter, "Neurophysiology,” 4th Edition, Arnold, London, 2003.

[25] R. Burton, “The Language of Smell,” Roultedge and Kegan Paul, London, 1976.

[26] R. I. Henkin, "Abnormalities of Taste and Olfaction in Patients with Chromatin Negative Gonadal Digenesis," The Journal of Clinical Endocrinology \& Metabolism, Vol. 27, No. 10, 1967, pp. 1436-1440. doi:10.1210/jcem-27-10-1436

[27] H. Nowakowski and W. Lenz, "Genetical Aspects in Male Hypogonadism,” Recent Progress in Hormone Research, Vol. 17, 1961, pp. 63-95.

[28] M. K. McClintock, "Menstrual Synchrony and Suppression,” Nature, Vol. 229, 1971, pp. 244-248. doi:10.1038/229244a0

[29] K. P. Skandhan, A. K. Pandya, S. Skandhan and Y. B. Mehta, "Synchronisation of Menstruation among Intimates and Kindreds," Panminerva Medica, Vol. 21, 1979, pp. 131-134.

[30] J. L. Veith, M. Buck and S. Getzaf, "Exposure to Men Influences the Occurrence of Ovulation in Women," Physiology \& Behavior, Vol. 31, No. 3, 1983, pp. 313315. doi:10.1016/0031-9384(83)90194-4

[31] H. C. Wilson, "Male Axillary Secretions Influence Women's Menstrual Cycles," Hormones and Behavior, Vol. 22, No. 2, 1988, pp. 266-271. doi:10.1016/0018-506X(88)90071-2

[32] W. B. Cutler, G. Preti and G. R. Huggins, "Sexual Behaviour Frequency and Biphasic Ovulatory Type Menstrual Cycle,” Physiology \& Behavior, Vol. 34, No. 5, 1985, pp. 805-810. doi:10.1016/0031-9384(85)90381-6

[33] H. Varendi, R. H. Porter and J. Winberg, "Does the Newborn Baby Find the Nipple by Smell?” Lancet, Vol. 344, No. 8928, 1994, pp. 989-990. doi:10.1016/S0140-6736(94)91645-4 
[34] N. Comfort, "Likelihood of Human Pheromones," Nature, Vol. 230, No. 5294, 1971, pp. 432-479. doi:10.1038/230432a0

[35] G. R. Huggins and G. Preti, "Volatile Constituents of Human Vaginal Secretions," American Journal of $\mathrm{Ob}$ stetrics \& Gynecology, No. 126, No. 1, 1976, pp. 129136.

[36] J. J. Sokolov, R. T. Harris and M. R. Hecker, "Isolation of Substances from Human Vaginal Secretions Previously Shown to be Sex Attractant Pheromones in Higher Primates," Archives of Sexual Behavior, Vol. 5, No. 4, 1976, pp. 269-274. doi:10.1007/BF01542078

[37] R. Waltman, V. Tricomi, G. E. Wilson, A. H. Lewin, N. L. Goldberg and M. M. Chang, "Volatile Fatty Acids in Vaginal Secretion. Human Pheromones?” Lancet, Vol. 302, No. 7827, 1973, p. 496. doi:10.1016/S0140-6736(73)92087-4

[38] E. V. Wilson and W. H. Bossert, "Chemical Communication among Animals," Recent Progress in Hormone Research, Vol. 19, 1963, pp. 673-716.

[39] R. L. Doty, M. Ford, G. Preti and G. R. Huggins, "Changes in the Intensity and Pleasantness of Human Vaginal Odours during Menstrual Cycle,” Science, Vol. 190, No. 4221, 1975, pp. 1316-1318. doi:10.1126/science.1239080

[40] J. S. Vierling and J. Rock, "Variations in Olfactory Sensitivity to Exaltolide during the Menstrual Cycle," Journal of Applied Physiology, Vol. 22, No. 2, 1967, pp. 311-315.

[41] D. Benton, "The Influence of Androstenol-A Putative Human Pheromone on Mood throughout Menstrual Cycle,” Biological Psychology, Vol. 15, No. 3-4, 1982, pp. 249-256. doi:10.1016/0301-0511(82)90047-3

[42] M. B. Hurwitz, "Sexual Dysfunction Associated with Infertility: A Comparison of Sexual Function during the Fertile and Non Fertile Phases of Menstrual Cycle," South African Medical Journal, Vol. 76, 1989, pp. 58-61.
[43] D. M. T. Fessler, "Rape Is Not Less Frequent during the Ovulatory Phase of the Menstrual Cycle,” Psychology, Evolution \& Gender, Vol. 5, No. 3, 2003, pp. 127-147. doi:10.1080/14616660410001662361

[44] A. S. Parkes, "Patterns of Sexuality and Reproduction," Oxford University Press, London, 1976.

[45] S. W. Gangestad, R. Thornhill and C. E. Graver-Apger, "Changes in Women's Sexual Interests and Their Partners' Materetention Tactics across the Menstrual Cycle: Evidences for Shifting Conflicts of Interest," Proceedings of the Royal Society B, Vol. 269, No. 1494, 2002, pp. 975-982. doi:10.1098/rspb.2001.1952

[46] M. G. Haselton and S. W. Gangestad, "Conditional Expression of Women's Desires and Male Mate Retention Efforts across the Ovulatory Cycle," Hormones and Behavior, Vol. 49, No. 4, 2006, pp. 509-518. doi:10.1016/j.yhbeh.2005.10.006

[47] E. G. Pillsworth and M. G. Haselton, "Male Sexual Attractiveness Predicts Differential Ovulatory Shifts in Female Extra-Pair Attraction and Male Mate Retention,” Evolution and Human Behavior, Vol. 27, No. 4, 2006, pp. 247-258. doi:10.1016/j.evolhumbehav.2005.10.002

[48] L. Keith, A. Dravnieks and B. K. Krotoszynski, "Olafactory Study: Human Pheromones," Archives of Gynecology and Obstetrics, Vol. 18, 1975, pp. 203-204.

[49] K. P. Skandhan, S. Amith, H. Vadodaria, B. N. Mazumdar, K. Dhuri and M. Gondalia, "Human Pheromone in Urine: A Study,” Communicated, 2012.

[50] A. Baleta, “Alleged Rape of 9-Month-Old Baby Shocks South Africa,” The Lancet, Vol. 358, No. 9294, 2001, p. 1707. doi:10.1016/S0140-6736(01)06779-4

[51] R. B. Everett and G. K. Jimerson, "The Rape Victim, A Review of 117 Consecutive Cases,” Obstetrics \& Gynecology, Vol. 50, No. 1, 1977, pp. 88-90. 